\title{
DAMPAK PARIWISATA TERHADAP SENI PATUNG TRADISIONAL DI DESA SILAKARANG
}

\author{
I Wayan Mudana \\ Jurusan Seni Rupa Murni, Fakultas Seni Rupa dan Desain, \\ Institut Seni Indonesia Denpasar, Indonesia
}

\begin{abstract}
: statue work of art produced by artists at the village of Silakarang is traditional work of art this is raised as a problem highlighting the existence and impact of traditional statue work of art produced by statue artists in the village of Silakarang. The aims of this study are to see the development traditional statue work of art and its existence if compared with modern statue. This study took twenty kinds consisting for sample of 10 traditional statue and 10 modern statue and 30 respondent of stone carver who were divided into three groups, group A,B, and C. They were all used as sample using “ Purposive Sampling". Data collection used observation technique, interview, documentation, and library research. The study employed descriptive analysis, that is, analysis technique analyzing the existence of traditional status work of art in four aspects: form, function, significance and marketing and analysis with impact; esthetic, social and culture, economic, and environmental.
\end{abstract}

Keywords: Traditional statue work o1' art and tourism.

Pengaruh pariwisata terhadap sosial budaya masyarakat Bali dapat dilihat dari berbagai kreativitas seni yang dilakukan oleh masyarakat, sistem organisasi kemasyarakatan yang dijalankan, serta karakteristik atau prilaku masyarakat Bali yang merupakan unsur utama ke Baliannya. Dari unsur seni budaya, pariwisata dapat mendorong masyarakat untuk menghidupkan kembali seni kebudayan asli yang sudah hampir terlupakan, dapat menggairahkan perkembangan kebudayaan asli, serta dapat menumbuhkan kreativitas seni masyarakat yang dapat memperkaya kasanah budaya Bali. Namun disayangkan kebanyakan motivasi mereka lebih pada komersialisasi, sehingga sering mengakibatkan terjadinya provanisasi benda-benda seni yang bersifat sakral dan tempat suci yang sering mendapatkan sorotan masyarakat banyak. Dari aspek keorganisasian, pariwisata dapat memperkokoh organisasi tradisional seperti banjar, desa pakraman, subak yang merupakan identitas masyarakat Bali yang menjadi salah satu daya 
tarik wisatawan. Sedangkan dari aspek prilaku dan pola hidup yang sering digunakan sebagai tolak ukur untuk menilai kebaliannya masyarakat Bali sudah adanya tedensi pergeseran, namun secara umum masyarakat Bali masih bisa mempertahankan karakteristik prilaku sebagai masyarakat Bali.

Khusus mengenai eksistensi seni budaya yang merupakan hasil karya masyarakat Bali asli yang belum dipengaruhi budaya asing (luar) yang sering diidentifikasikan sebagai budaya tradisional yang mencerminkan identitas warna lokal (budaya lokal) Dalam melihat pengaruh pariwisata terhadap budaya lokal maka dalam penelitian ini akan diteliti tentang salah satu unsur seni budaya yang berupa karya seni patung yang dihasilkan oleh masyarakat Desa Silakarang, Singapadu Kaler, Sukawati, Gianyar. Lokasi ini merupakan jalur pariwisata yang sering dilewati bahkan dikunjungi oleh wisatawan yang membeli dan memesan patung. Sering sekali patung yang dipesan oleh wisatawan sesuai dengan desain yang mereka kehendaki, sehingga eksistensi patung tradisional terancam perkembangannya bahkan dikwatirkan terancam kepunahannya. Apalagi dengan berkembangnya kunjungan wisatawan dari berbagai belahan dunia yang memungkinkan banyak ide atau desain-desain yang bervaraiasi yang mengapresiasi patung tradisional. Sehingga patung yang dihasilkan tidak lagi memberikan warna lokal asli daerah Bali, tetapi lebih pada dominasi budaya wisatawan terhadap budaya lokal.

Penelitian yang dilakukan ini bersifat deskriptif dan komperatif, yaitu penelitian yang menjelaskan suatu fenomena dan membandingkan antara satu fenomena dengan fenomena lainnya. Dalam penelitian ini akan menjelaskan tentang eksistensi seni patung tradisional akibat adanya pengaruh pariwisata, dan membandingkan antara pendapatan yang diterima oleh masyarakat dari pembuatan patung tradisional (warna lokal) dengan pendapatan yang diterima dari pembuatan patung modern.

Penelitian ini dilakukan di Desa Silakarang yang merupakan jalur menuju kawasan pariwisata Ubud dan mulai dilakukan dari bulan Oktober 2005 sampai bulan Februari 2006. Alasan pengambilan lokasi ini, karena di Desa Silakarang yang $90 \%$ masyarakatnya sebagai pematung batu padas dan merupakan daerah pematung pertama di daerah Gianyar, yang sering disebut sebagai sentral seni patung batu padas. Karya-karya seni patung yang dibuat di Silakarang dianggap bisa mewakili eksistensi seni patung tradisional kalau dilihat dari aspek bentuk, fungsi dana makna, dan dampak pariwisata dilihat dari aspek estetik, sosial budaya, ekonomi, dan lingkungan. Sebagai jalur wisata yang banyak dilewati oleh para wisatawan, transaksi bisnis antara para wisatawan dengan para pengusaha sangat besar pengaruh pariwisata terhadap eksistensi budaya lokal khusunya seni patung tradisional.

\section{TINJAUAN PUSTAKA}




\section{Pariwisata}

Spillane (1987:21) menyatakan: pariwisata adalah perjalanan dari satu tempat ke tempat lain, bersifat sementara, dilakukan perorangan maupun kelompok, sebagai usaha mencari keseimbangan atau keserasian dan kebahagiaan dengan lingkungan hidup dalam dimensi sosial, budaya, alam, dan ilmu.

Pariwisata berarti perpindahan orang yang bersifat sementara ke suatu daerah di luar tempat tinggalnya dan tempat kerjanya sehari--hari, aktifitas yang berlangsung selama mereka tinggal di tempat tujuan dan fasilitas yang dibuat untuk memenuhi kebutuhannya.

Sedangkan jenis pariwisata ditentukan menurut motif tujuan perjalanan, sehingga pariwsata dapat digolongkan menjadi 6 jenis (Spillane,op.cit.p.28-31), yaitu:

1) Pariwisata untuk Menikmati Perjalanan (Pleasure Tourism)

Tujuan perjalanan ini adalah untuk berlibur, mencari udara segar, mengendorkan ketegangan syarafnya, melihat sesuatu yang baru, menikmati keindahan alam, mengetahui hikayat rakyat setempat, mendapatkan ketenangan dan kedamaian di luar kota maupun menikmati hiburan di kota-kota besar.

2) Pariwisata untuk Rekreasi (Recreation Tourism)

Dilakukan oleh orang dengan tujuan untuk beristirahat, memulihkan kesegaran jasmani dan rohaninya, yang biasanya mereka tinggal di daerah pantai, pegunungan, dan pusat-pusat peristirahatan atau kesehatan dan tinggal lebih lama.

3) Pariwisata untuk Kebudayaan (Cultural Tourism)

Tujuannya untuk belajar di pusat-pusat pengajaran dan riset, mempelajari adat-istiadat dan cara hidup negara lain, mengunjungi monumen dan peninggalan bersejarah, pusat-pusat kesenian, keagamaan, serta ikut dalam festival-festival seni musik, teater, tarian rakyat.

4) Pariwisata untuk Olah Raga (Sports Tourism). Jenis ini dibagi dua, yaitu:

Big Sports Events, yaitu peristiwa olah raga besar seperti: Olympiade Game, dan kejuaraan dunia lainnya. Sporting Tourism of the Practitioners, berupa latihan olah raga, berburu, memancing, mendaki gunung.

5) Pariwisata untuk Urusan Usaha Dagang (Business Tourism)

Jenis ini sering disebut sebagai Profesional Travel atau perjalanan yang ada kaiatannya dengan pekerjaan atau usaha dagang.

6) Pariwisata untuk Berkonvensi (Convention Tourism)

Tujuannya untuk mengikuti berbagai konvensi atau konferensi baik bersifat nasional maupun bertaraf internasional (MICE). 


\section{Seni Patung}

Seni patung merupakan suatu pernyataan pengalaman artistik lewat bentuk-bentuk tiga dimensional. Menurut Suandi (1999:32): seni patung adalah sebagai suatu seni perencanaan dan pengkonstruksian bentuk-bentuk tri matra dengan sifat-sifat sebagai berikut: a) Menggambarkan obyek sebenarnya atau khayal, b) Menyajikan sebuah rancangan bentuk tri matra, dan c) Mensugestikan berjenis gagasan, perasaan, dan pengalaman lain.

Untuk mengekpresikan apa yang terkandung di dalam jiwa seniman sampai terwujud suatu karya seni patung adalah melalui proses kejiwaan yang disadari atas pengalaman, intelektual, daya imajinasi, daya kreativitas yang tinggi, dan beberapa faktor yang lain, seperti faktor internal dan eksternal seniman. Faktor internal menyangkut bakat dan kemampuan seniman terhadap apresiasi dan teknik, sedangkan faktor eksternal menyangkut tentang pengalaman serta lingkungan yang mendukung (kepercayaan dan spiritual).

\section{Kondisi Desa Silakarang}

Desa Silakarang termasuk wilayah Singapadu Kaler, Kecamatan Sukawati, kabupaten Gianyar, Propinsi Bali, terletak di sebelah barat kabupaten Gianyar dengan batas-batas: di sebelah penghujung utara Desa Singakerta (kecamatan Ubud), di sebelah barat Desa Mambal (kecamatan Abiansemal, Badung), sebelah selatan Desa Singapadu Tengah (kecamatan Sukawati Gianyar), sebelah timur Desa Lodtunduh (kecamatan Ubud, kabupaten Gianyar). Secara geografis, desa Silakarang; merupakan dataran rendah dengan ketinggian 250 sampai 300 meter di atas permukaan air laut dan panas suhu 24 sampai 33 derajat celcius. Luas wilayah 3.000 meter persegi (monografi desa Silakarang 1998).

Berdasarkan data statistik tahun 1998 penduduk desa Silakarang adalah $331 \mathrm{KK}$ dengan jumlah penduduk 1.324 yang mata pencahariannya sangat beragam.

Tabe1 1. Komposisi Mata Pencaharian Penduduk Silakarang

$\begin{array}{lll}1 & \text { Bertani } & 10 \\ 2 & \text { Pematung ukir } & 662 \\ 3 & \text { PNS/ABRI } & 52 \\ 4 & \text { Dagang } & 101 \\ 5 & \text { Buruh } & 489 \\ & \text { Jumlah } & 1324\end{array}$


Berdasarkan atas uraian tersebut, Desa Silakarang berpotensi untuk dikembangkan sebagai salah satu sentra industri yang bergerak dalam sektor seni dan kerajinan. Sebagian besar penduduknya memilih mata pencaharian mematung/ukir sehingga untuk kedepannya dapat dijadikan andalan untuk menopang kehidupan masyarakat. Industri ini juga dapat dijadikan suatu pembinaan dalam menyongsong pasar bebas yang banyak dikunjungi pembeli dunia karena sebagai rekanan bisnis (manca negara) yang memiliki disain diproduksi di Silakarang sehingga terjadi akulturasi pemikiran seni antara pemahaman terhadap seniman lokal dengan karya seni tradisinya dengan orang asing tentang kebebasan berekpresi.

\section{Pemasaran Karya Seni Patung}

Tabel 2. Produksi Patung Tradisional dan Patung Modern Tahun 2005

$\begin{array}{lllll}1 & \text { Patung Brahma } & \text { Patung Ikan } & 400 & 1.460 \\ 2 & \text { Patung Wisnu } & \text { Patung Kura kura } & 440 & 1.456 \\ 3 & \text { Patung Hanoman } & \text { Patung Kodok } & 400 & 2.904 \\ 4 & \text { Patung Ganesia } & \text { Patung Gajah } & 588 & 732 \\ 5 & \text { Patung Twalen } & \text { Patung Torso } & 208 & 312 \\ 6 & \text { Patung Wredah } & \text { Dewi Tara } & 216 & 396 \\ 7 & \text { Patung Singa } & \text { Patung Buda } & 448 & 1.448 \\ 8 & \text { Patung Dedari } & \text { Patung abstrak } & 204 & 150 \\ 9 & \text { P Buta nawasari } & \text { Patung Mengantuk } & 424 & 2.896 \\ 10 & \text { P Naniswara } & \text { Patung Melamun } & 456 \_ & 2.908 \\ & & \text { J u m 1 a h } & 3.784 & 14.662 \\ & & \text { Komposisi (\%) } & 20,51 & 79,49\end{array}$

Sumber data: Pengusaha Patung di Silakarang

Pemasaran karya seni patung yang tejadi di Desa Silakarang tidak sepenuhnya dibeli oleh wisatawan, namun banyak pembeli domestik, bahkan ada orang Bali. Patung yang dibeli oleh para wisatawan kebanyakan adalah patung modern, namun ada juga yang membeli patung tradisional. Penjualan patung yang terjadi sangat mempengaruhi besarnya tingkat produksi yang dihasilkan oleh para pematung dari banjar Silakarang. Untuk itu di sini akan disajikan produksi antara patung tradisional dengan patung modern yang dihasilkan oleh para pengusaha patung di banjar Silakarang. Besarnya 
perbandingan jumlah patung tradisonal dengan patung modern dapat dilihat dari bagaimana posisi produksi patung tradisional dengan patung modern dengan adanya perkembangan pariwisata.

Dari tabel di atas dapat dijelaskan bahwa produksi patung tradisional hanya sebesar $20,51 \%$ dari produksi total patung dan produksi patung modern sebesar $79,49 \%$. Ini berarti produksi patung modern lebih besar dari produksi patung tradisional, namun produksi patung tradisional masih cukup besar peluang pasarannya.

\section{DAMPAK PARIWISATA TERHADAP KARYA SENI PATUNG}

Pariwisata membawa perubahan yang sangat besar terhadap perkembangan karya seni patung di Desa Silakarang, serta memiliki dampak yang sangat luas terhadap tatanan dan nilai dalam berkarya seni. Perubahan tersebut dapat sebagai pendorong ke arah perkembangan, pemeliharaan, pelestarian bahkan resiko terhadap lingkungan sosial maupun lingkungan alam. Adaptasi masyarakat lokal dengan wisatawan selain memiliki latar belakang ketertarikan terhadap, pandangan hidup (Agama Hindu), adat istiadat, kepercayaan, dan juga dilatar belakangi oleh ketertarikan atas produksi seni dan kerajinan (seni patung). Para seniman sangat adaptip terhadap ide-ide yang dibawa wisatawan dalam usaha menciptakan disain patung baru. Wisatawan juga sangat menghargai karya seni patung tradisional sebagai identitas warna lokal yang harus dijaga dan dikembangkan, dengan memasukan inovasi-inovasi baru. Dari akulturasi pemahaman terhadap ide dengan kultur berbeda berbeda, muncullah ide-ide kreatif, selain untuk memenuhi kebutuhan lokal juga untuk memenuhi kebutuhan wisatawan.

Dari aspek sosial budaya; Dengan tidak mengurangi makna positif dari pariwisata, harus diakui pariwisata menimbulkan konflik kepentingan antara pelestarian dan pengembangan terhadap produk lokal. Melihat perkembangan patung di Silakarang dari generasi ke generasi terus meningkat, disain dan produk semakin bertambah besar dengan kualitas mutu meningkat. Sehingga komoditas para seniman dengan karya seni patungnya berkembang menjadi suatu bagian dari industri pariwisata yang memberikan kepuasan atas barang dan jasa. Untuk menjaga eksistensi dan mencermati dampak yang mempengaruhi seniman dalam berkreatifitas lebih maju, dapat bersaing, hak cipta para seniman harus mendapat perlindungan dari pemerintah. Sumber-sumber yang menyebabkan persaingan itu yaitu: a) perebutan sumber daya; dengan menguasai sumber daya baik itu merupakan sumber daya alam, manusia maupun teknologi secara tidak langsung sudah dapat memenangkan persaingan, b) perluasan batas-batas sosial budaya, persaingan bisa muncul dalam kehidupan majemuk karena perbedaan tradisi, 
bahasa, hukum, dan identitas sosial dapat menyatu dalam kepentingan politik, c) benturan kepentingan politik, idiologi dan agama.

Aspek ekonomi, berkaitan dengan pemenuhan kebutuhan psikologis berupa: sandang, pangan, papan, dan kebutuhan mewah serta berkaitan dengan kebutuhan yang bersifat intrinsik yaitu: kepuasan, kesenangan, kedamaian. Dengan adanya kedua kebutuhan tersebut, dalam idustri pariwisata yang memiliki kekuatan ekonomi mampu mengendalikan para seniman dan para pemilik kios-kios seni, untuk membuat disain-disain baru sesuai dengan kebutuhan pasar. Disatu sisi pesanan/orderan wisatawan sangat dibutuhkan karena memiliki potensi menghasilkan pendapatan untuk menopang kebutuhan hidup. Dalam posisi tidak berdaya para pematung menjadi sangat bergantung pada wisatawan dan mau mengerjakan apa saja yang menjadi kebutuhan pasar yang dikehendaki wisatawan. Sehingga terjadilah provanisasi untuk dijadikan model dalam industri, sehingga lahirlah produksi masal sebagai cerminan budaya populer. Sedangkan dari aspek lingkungan; berkaitan dengan kebersihan, keselamatan lingkungan, dan pembangunan berkelanjutan.

Dampak Pariwisata terhadap seni patung di Silakarang:

\section{Aspek Estetis}

Dengan adanya pariwisata, karya seni patung di Desa Silakarang mengalami perkembangan sangat pesat, bila dilihat dari jumlah penjualan, pemasaran, upah/pendapatan, dan kreasi disain. Identitas disain lokal yang mengangkat tema-tema lokal berkaitan dengan simbolik, memiliki pangsa pasar lokal, sehingga produk karya seni patung tradisional perkembangannya sangat terbatas. Sedangkan disain seni patung yang dikonsumsi oleh pariwisata dikembangkan dengan mengadopsi ide-ide dari wisatawan yang memiliki latar belakang berbeda dari berbagai negara. Akulturasi warna lokal dengan budaya pariwisata melahirkan karya seni patung yang bersifat universal, dapat mewakili dari berbagai keinginan masyarakat dunia.

Para seniman dalam berkreasi, menciptakan produk seni patung untuk memenuhi keinginan wisatawan sebagai wujud jual beli (komersial) dan melestarikan nilai-nilai tradisional adalah merupakan tantangan baru, harus dicermati dari urgensitasnya. Sehingga dampak estetik wujud karya seni patung tradisional dalam kaitannya dengan pariwisata, dikatakan sebagai berikut:

Dampak positif dari pariwisata terhadap estetika karya seni patung yang berkembang di Desa Silakarang

a) Dapat memahami kebutuhan estetis wisatawan dari berbagai negara yang memiliki kultur berbeda terhadap produk karya seni patung. Sebab setiap negara memiliki panatisme dan identitas terhadap karya seni.

b) Semakin meningkatnya keragaman dari disain-disain patung, serta berkembangnya pengetahuan tentang motif untuk menunjang 
keindahan. Sehingga wisatawan memiliki alternatip pilihan yang lebih banyak sesuai dengan selera kebutuhan.

e) Memacu semangat untuk berinovasi dan berkreatifitas untuk melahirkan produk-produk seni patung baru, untuk selalu eksis, berkelanjutan dapat memenuhi kebutuhan wisatawan akan disain dari berbagai musim.

f) Untuk memperlihatkan identitas, kepribadian terhadap karya-karya yang diperkenalkan pada wisatawan. Identitas seseorang tercermin pada karyanya. Karya karya yang memiliki identitas serta kualitas seni memadai akan menjadi incaran para pembeli.

Sedangkan dampak negatif dari estetika karya seni patung tradisional di Desa Silakarang

a) Semakin ditinggalkannya pakem-pakem dalam bentuk patung tradisional (warna lokal) seperti: komposisi, proporsi, tata rias/busana. Membuat komposisi dalam seni patung tradisional merupakan proses awal pembentukan yang diawali dari nyalonan dan ngetekung untuk memproleh yang harmonis dan seimbang. Proporsi, berkaitan dengan kegunaan patung yang terdiri dari: Lanjar ditempatkan pada tempat ketinggian, Nyepek ditempatkan pada tempat yang ideal, dan Rentet untuk melahirkan bentuk patung yang disharmonis.

b) Komersialisasi membawa perubahan terhadap mental seniman, yang lebih mengejar keuntungan ekonomi.

c) Penyederhanaan bentuk untuk mempercepat proses pengerjaan, mengurangi nilai estetis dari kaya seni patung.

d) Keindahan sudah diukur dengan uang (budaya hidonisme). Uang memiliki kendali yang sangat besar, sehingga karya-karya yang dikerjakan secara berkelompok sulit untuk mendapatkan hasil maksimal.

\section{Aspek Sosial-Budaya}

Dalam teori evolusionisme multilinier mengemukan bahwa proses perkembangan berbagai kebudayaan itu memperlihatkan adanya beberapa proses perkembangan yang sejajar. Kesejajaran itu terutama nampak pada unsur yang primer sedangkan unsur kebudayaan yang sekunder tidak nampak perkembangan yang sejajar dan hanya nampak perkembangan yang khas. Proses perkembanan yang tampak sejajar mengenai beberapa unsur kebudayaan primer disebabkan oleh karena lingkungan tertentu memaksa terjadinya perkembangan ke arah tertentu.

Adapun dampak positif yang disumbangkan baik yang berupa manfaat maupun keuntungan yang diperoleh atau dirasakan oleh masyarakat Silakarang serta perubahan yang bersiilat positif yang terjadi akibat adanya perkembangan pariwisata yang meliputi: 
a) Dapat memacu motivasi kreativitas seni para pematung untuk berkarya lebih inovatif dan lebih variatif sesuai dengan kebutuhan pariwisata dan meningkatnya persaingan bisnis.

b) Meningkatkan keterampilan dan pengetahuan para pematung tentang karya seni patung khususnya dan karya seni lainnya, walaupun masih sedikit yang mengatakan yaitu sebesar $16,67 \%$

c) Meningkatkan desiplin kerja para pematung terutama betul betul memanfaatkan jam kerja sepenuhnya dalam rangka memenuhi pesanan wisatawan, supaya tidak kehilangan kepercayaan.

d) Dapat mengetahui budaya dari berbagai negara terutama melalui berbagai pesanan karya seni di luar karya seni patung tradisional yang dikerjakan oleh pematung seperti membuat bentuk-bentuk karya seni abstrak yang berupa patung dari batu padas dan batu putih .

f) Dapat meningkatkan kualitas yadnya yang dilakukan di pura Kahyangan terutama dari tingkatan upacara yang dilakukan tanpa adanya perasaan yang terbebani oleh banyaknya iuran yang dikeluarkan oleh masyarakat.

g) Dapat meningkatkan jumlah masyarakat yang terjun ke sektor seni umumnya dan seni patung khususnya, sehingga menjadikan masyarakat Silakarang secara mayoritas sebagai masyarakat seni patung terutama para lelakinya.

h) Dapat melestarikan budaya bangunan tradisional yang adi luhung, karena sebagian besar bangunan masyarakat yang ada di banjar Silakarang menggunakan gaya bangunan stil Bali yang dihiasi dengan patung tradisional sebagai ornamennya.

Sedangkan dampak negatif yang diakibatkan dengan adanya perkembangan pariwisata yang terjadi di Silakarang baik yang berupa kerugian maupun perubahan yang tidak diharapkan dapat berupa:

a) Berkurangnya minat generasi muda di Silakarang untuk menjadi petani, karena masyarakatnya sebagian besar (hampir semuanya) beralih profesi dari petani menjadi masyarakat seni atau terjun ke profesi seni, sehingga tidak dapat melestarikan budaya subak yang merupakan budaya Bali yang sudah terkenal ke manca negara.

b) Munculnya budaya (pola hidup) konsumtif, atau terjadinya perubahan pola hidup dari pola hidup sederhana menjadi pola hidup konsumtif, di mana masyarakatnya hampir semua menerapkan pola hidup mewah dan pola hidup instan dalam mengejar prestise.

c) Berkurangnya sifat kebersamaan karena adanya pengaruh budaya barat terutama tuntutan dari pengerjaan patung modern yang lebih bersifat individual tidak seperti dalam pengerjaan patung tradisional yang lebih bersifat komunal atau secara berkelompok.

d) Berkurangnya motivasi masyarakat untuk melanjutkan sekolah lebih tinggi karena masyarakatnya sudah menikmati hasil dari karya seni 
patung yang dianggap lebih banyak apabila dibandingkan dengan menjadi pegawai negeri.

e) Hilangnya batas penyengker(telajakan/sampih) rumah yang telah dijadikan stand untuk penjualan patung, bahkan fungsi rumah sudah dijadikan tempat untuk memajangkan patung, sehingga tidak lagi mengikuti ketentuan sikut satak atau sudah bertentangan dengan konsep tri hita karana.

\section{Aspek Ekonomi}

Dampak positif dari perkembangan pariwisata yang berupa manfaat atau keuntungan yang diperoleh atau dirasakan oleh masyarakat Silakarang serta perubahan yang bersifat positif yang terjadi di banjar Silakarang, yang meliputi:

a) Meningkatkan pendapatan para pematung dari berbagai kelas pematung, di mana pendapatan yang mereka terima lebih besar apabila mengerjakan patung modern dibandingkan dengan mengerjakan patung tradisional.

b) Dapat menyediakan lapangan kerja baik secara sektoral maupun secara menyeluruh bagi banjar Silakarang.

c) Memacu tumbuhnya interpreneuship (jiwa kewirausahaan) bagi para pematung khususnya dan masyarakat Silakarang umumnya, walaupun pola bisnis tradisional.

d) Memacu munculnya usaha di sektor lain yang dapat menyediakan fasilitas baik kepada pengusaha patung maupun kepada pematung itu sendiri, dimana salah satu contohnya akan muncul usaha perbankan yang berupa BPR (Bank Perkreditan Rakyat), melihat banyaknya kebutuhan dana yang diperlukan oleh para pengusaha patung terutama untuk melakukan pembelian bahan dan pembayaran upah para pematung.

e) Meningkatnya harga dan sewa tanah terutama di pinggir jalan, sehingga dapat memberikan keuntungan bagi masyarakat yang tidak memiliki kemampuan untuk membuka usaha terutama secara finansial, sehingga dapat memacu perkembangan ekonomi pedesaan.

Sedangkan dampak negatif yang diakibatkan dengan adanya perkembangan pariwisata yang terjadi di Silakarang baik yang berupa kerugian maupun perubahan yang tidak diharapkan dapat berupa:

a) Terjadinya over supply (kelebihan penawaran) patung, karena masyarakat banyak yang beralih profesi dari petani ke pematung, disamping adanya penawaran patung dari jawa yang sangat banyak.

b) Ada kecendrungan meningkatnya biaya hidup masyarakat Silakarang karena adanya perubahan gaya hidup, sehingga akan dapat mengurangi kebiasaan untuk menabung. 
c) Kalau terjadi penurunan pariwisata yang tajam terutama pesanan dari wisatawan berkurang akan menyebabkan masyarakat Silakarang kehilangan kesempatan untuk mendapatkan pendapatan, sehingga masyarakat Silakarang akan mengalami kelaparan atau minimal harus berutang untuk memenuhi kebutuhan hidupnya.

d) Pendapatan para pematung sangat berfluktuasi, karena harga patung tergantung dari perkembangan pariwisata. Di mana pada saat tamu ramai atau pesanan banyak harga patung meningkat.

\section{Aspek Lingkungan}

Dampak positif dari perkembangan pariwisata yang berupa perubahan lingkungan yang lebih baik dan yang lebih bermanfaat yang dirasakan oleh masyarakat Silakarang serta perubahan yang berisfat positif yang terjadi di banjar Silakarang, yang meliputi:

a) Terjadi perubahan muka jalan di sepanjang Desa Silakarang dari tembok penyengker menjadi bengkel-bengkel karya seni yang sekaligus sebagai halaman seni (art gellery) patung yang menunjukkan betapa indahnya muka jalan di sepanjang desa Silakarang.

b) Kebersihan lingkungan di sepanjang jalan raya terjaga sepanjang hari dari sampah, walaupun ada kreativitas seni yang dilakukan disamping atau di belakang gallery tersebut, namun tidak terkesan kumuh. Bahkan justru dapat menarik wisatawan untuk menyaksikan kreativitas seni tersebut secara langsung.

Sedangkan dampak negatif yang diakibatkan dengan adanya perkembangan pariwisata yang terjadi di banjar Silakarang baik yang berupa kerugian maupun perubahan kondisi lingkungan yang tidak diharapkan dapat berupa:

a) Ekplotasi tebing untuk mendapatkan material patung (batu padas) yang berlebihan akan merusak lingkungan dan rawan bahaya longsor. Sisasisa bahan batu padas sering jatuh ke saluran air, dan saluran air yang ada di muka gallery ditutup dengan plat atau dengan trotoar, sehingga saluran air itu dangkal, menyebabkan pada musim hujan terjadi kebanjiran di jalan raya, walaupun tidak terlalu lama. Namun hal ini tetap menjadi pemandangan yang tidak higienis dan kurang asri, selain akan menimbulkan kemacetan lalu lintas. Banyaknya lahan persawahan terutama di pinggir jalan berubah fungsi menjadi gallery menyebabkan paru-paru desa di banjar Silakarang berkurang.

b) Berbaurnya rumah dengan gallery, sehingga tidak nampak jelas batas rumah dengan gallery. Ini berarti penanataan lingkungan yang dilakukan melanggar konsep Tri Hita Karana . 
c) Ada perbedaan penataan lingkungan antara di pinggir jalan raya dengan di pinggir jalan desa (agak di dalam), di mana di jalan raya penataan lebih indah dan lebih bersih, karena ada gallery.

\section{SIMPULAN}

Melihat dampak yang diakibatkan dengan adanya perkembangan pariwisata di banjar Silakarang, di mana lebih banyak dampak positifnya, sehingga secara menyeluruh dari aspek ekonomi pariwisata banyak memberikan nilai tambah yang berharga kepada masyarakat Silakarang, walaupun ada beberapa kerugian yang akan dialami, namun hanya sebatas kecendrungan yang terjadi, sehingga perkembangan pariwisata dari aspek ekonomi secara riil banyak memberikan kemajuan kepada masyarakat Silakarang terutama dari peningkatan pendapatan dan perkembangan ekonomi lainnya.

\section{DAFTAR RUJUKAN}

Tim. 1998. Monografi Desa Silakarang.

Soedarso, SP. 1990. Sejarah Perkembangan Seni Rupa Modern, Yogyakarta, Institut Seni Indonesia.

1990. Tunjuan Seni, Yogyakarta, Saku Dayar Sana.

Spillane, James J. 1987. Ekonomi Pariwisata: Sejarah dan Prospekrrya, Kanisius, Yogyakarta.

Swandi, I Wayan. 1999. Inovasi Ida Bagus Tilem dalam Seni Patung Bali Modern, Denpasar, Program Pasca Sarjana Universitas Udayana. 